\title{
Mediation as one of the Models in Alternative Dispute Resolution in the Nagori Village in Tanah Java District of Simalungun
}

\author{
Rosnidar Sembiring \\ Law Faculty \\ University of Sumatera Utara \\ Medan, Indonesia \\ oni_usu@yahoo.com
}

\begin{abstract}
Since the enactment of Law No. 32 / 2004 regarding Regional Government jo. Government Regulation No. 76 / 2001 on General Guidelines for Arrangement on Villages, then reinforced by the issuance of Law No. 6 / 2014 regarding Village has become the legal basis which empowers the Village Head to reconcile disputes that occur in village communities with the help of Village Adat Institutions. This research was conducted in Nagori village, Tanah Simalungun Subdistrict, which consist of 20 (twenty) villages using descriptive analysis method. The pattern of dispute settlement is an alternative dispute resolution pattern by involving the role of Village Head, Customary Institution, customary figure, religious figure and intellectual as mediator in reaching peace agreement.
\end{abstract} dispute

Keywords - mediation; nagori-nagori; tanah java district;

\section{INTRODUCTION}

In its purpose, human, in any place or era, live in groups or together. This is according to the statement of Aristotle (384 322 BC), a Greek scholar who said that human is ZOON POLITICON, a creature that basically always want to gather with other human, namely social creature. And also because of the character of wanting to gather with others, human is called as social creature. [1]

As plural society, the life of Indonesian society is close to conflict especially from the clash of values in society. Satjipto Raharjo said that to admit plurality is to admit conflit as something potential. By that, the philosophy is by processing the conflict to be productive for society. [2]

Adat law as the reference or society norm in Indonesia is to be expected to create safety and order, but in a society, disputes tend to occur which is capable of disrupting the peace and order, so an alternative dispute resolution is necessary in bringing back the justice and solving the problem. [3]

Alternative Dispute Resolution or ADR, is based on the intention of solving the issue better and more efficiently solved for the disputed parties in a discreet, voluntary and adjustable process to the need and purpose of the parties and also easily controlled by them. [4]
The legal culture of solving disputes through alternative dispute resolution is the trend in the current world with different backgrounds. For western countries like the US, alternative dispute resolution is more pointed to the pragmatist consideration in the eastern countries, it was encouraged by the living and developing values in society. [5]

Indonesian society has acknowledged the alternative dispute resolution, especially mediation as one way to settle an issue. But the term used were different, it was called as deliberation for a decision making. For example: an Adat leader as a third party in solving disputes occurred in society in land, debt, marriage, and other issues. The dispute resolution was handled by the Adat leader based on the Adat law of the land and the good will of the parties and handler or mediator. Mediation as one of the alternative dispute resolutions has its own special attraction in Indonesia for its harmony with traditional social - culture system based on the principle of deliberation.

In the dispute resolution with deliberation, as known by the villagers, the mediator was the chief of the village who is aso the adat leader or a religious person. This is based on the general explanation number 9 of Act number 221999 of Regional Government stating that: "based on the origin of the village, the chief has the authority to make peace of the people". Then, Article 16 of Government Regulation number 76 of 2001 regarding General Guidance of Village Regulation, it appoints that one of the jobs and responsibilities of the chief of the village is to make peace of the dispute occurred in the village.

In Act number 6 of 2014 of Village there is also the role of chief of village in solving the dispute in the village in Article 26 (1) Act number 6 of 2014: "the chief of the village is obliged to implement the development of the village and supervising the resident of the village and also functioning them" then, in Article 26 (4) k, as intended in article (1), the chief of the village is obliged to solve the dispute occurred in the village.

In Act number 6 of 2014 regarding the Village or in Government Regulation number 43 of 2014 of Implementation rule of Act number 6 of 2014 of the Village, it doesn't explain 
the kind of dispute, mechanism or procedure or the decision product of the dispute resolution conducted by the chief.

The procedure or mechanism of dispute resolution of the chief which is not based on the legislation is the focus of this research in regards to ho the chief run his role in resolving the issue especially in Tanah Java District of Simalungun in North Sumatera Province.

The renewal of legislation is now become necessary, and functioned as the regulation tool or development media, setting the society to the wanted situation. [6]

\section{ISSUES}

Based on the explanation above, this research is to learn the procedure or mechanism of dispute resolution with mediation pattern happens in the villagers through the chief of the village in Tanah Java District of Simalungun in North Sumatera.

\section{RESEARCH METHOD}

The research method used is empirical research of analytic-descriptive, where from this research whole description can be concluded regarding the dispute resolution of the chief of the village which will then analyzed carefully in the legal aspects related to the activity of the chief in solving the disputes in Tanah Java District of Simalungun in North Sumatera.

\section{EXPLANATION}

Basically, dispute resolution can be done in two ways, litigation and non litigation. Litigation can create one adversarial verdict which is not capable in assuring the purpose of the parties because the verdict is a win lose solution, and with winning and losing parties, one will always be at loss causing a new dispute between the disputed parties. let alone the slow and more expensive process. Non litigation can be a win win solution for it is done with the agreement and deliberation of the parties so it can create a decision that can be accepted well by both parties and it can be kept secret since there is no obligation for an open hearing or proceeding or to be published. This non litigation is also known as Alternative Dispute Resolution. [7] Mediation is the assisting tool in solving disputes that can aid the parties in achieving a more satisfying resolution with win-win solution, some say that mediation can be used to achieve social justice by growing the creativity, the functioning of the society and relocation of power between groups. Besides that, the power of mediation has the ability in changing the relationship and growing the creativity in communication by functioning individual and growing the respect of each other. [8]

In Indonesia, the dispute resolution with ADR is not something unknown or new to the values of the nation because the soul ad character of Indonesia is well known for its kinship and cooperation in solving disputes. In many tribes of Indonesia, deliberation usually used to make decision. In the Karonese, runggun is a forum for the indigenous people to solve an issue, in Minangkabau, the salvation is with the existence of a judge as mediator or conciliator. [9]
Alternative dispute resolution is part of the Indonesian culture based on three principles of harmony, decency and conformity.

According to Koesnoe, harmony is a cooperation as the guidance in solving adat law issue, and harmony is also a principle related to the view and the character of people in facing the life with adat as accepted for peace and welfare. One needs other so that everyone is the concern of anyone for the peaceful life of society. Decent is a definition related to a harmony and ratio in valuing one good situation in an alteration. For that, harmony is derived from decency and ratio. [10]

Basically, the culture of conciliation or deliberation is existed in Indonesia all the time. Many tribes in Indonesia has the culture of a peaceful way of resolving disputes, for example in the culture of Java, Bali, South Sulawesi, West Sumatera, South Sumatera, Lampung, Lombok, Irian Jaya, and Toraja. For Japanese, litigation has been judged wrong morally, and also the sign of rebellion and endanger harmonize social relationship. [11]

With an almost similar culture with Japan, Indonesia is a little bit unique in 'digesting' modern law values. For the Japanese, regardless the strong wave of modernization, the still hold on to the basic harmony values to settle the disputes, for Indonesia, modernization is influencing the culture and structure of the societal life. According to Noda, for a well respected Japanese, law is something unlikeable, or hated. To propose a suit to the court to protect himself even in private matter is shameful. [12]

Alternative Dispute Resolution Institution is actually a model of dispute resolution which is matched to the villagers character, compared to the vibe of litigation or a win-lose risk and the tendency to rely more on materialistic judgment by disobeying social factor. Alternative Dispute Resolution put harmonization, kinship, and consider many interests which is identical with the character of villagers which prioritize senses without neglecting rationality, communal character, and pure relationship and care for others as a society which interaction is based on high voluntary to sacrifice for others. [13]

Some mediation principles are voluntarily obeying the agreement of parties in private matter simply and in discreet and with the character as the facilitator. Hese principles are their own attraction from mediation since in mediation, the parties can enjoy closed for public principle which is not provided for litigation with its open for public character. [14]

Mediation is not a legal institution, but a social institution. Because of that, mediation is not a legal job, even though it is mainly regarding solving legal issues. Because of this mediator is not always a legal expert. It can be a biologist, financial expert, botanist, or any other expert according to the field of disputes. The main requirement of a mediator is the ability to assure the disputed parties to find the best solution to their dispute (the skill in mediation). An economist can be a goof mediator outside litigation in solving business dispute . by considering economic risk when bringing the dispiue to court. Because of this, mediation is open for any profession including religious people or public figure. Social or religious 
approach can be the starting point in solving family issue without having to touch the law. [15]

By looking at some benefit of mediation, one of them is the simplicity, private, and discreet, mediation should be a better choice. Beside the benefits Indonesia has known the values of mediation which tend to be called as deliberation. So, in the research which conducted in Tanah Jawa District of Simalungun, and alternative dispute resolution form has been known with the role of village chief, adat scholar, religious figure as the mediator.

The role or function of village chief as the mediator in disputes in this area is strengthen with the enactment of Act number 6 of 2014 of the Village which assert the function of village chief as dispute resolution. Article 26 (1) mentioned that the chief of the village is obliged to implement the development of the village and supervising the resident of the village and also functioning them then, in Article 26 (4) k, as intended in article (1), the chief of the village is obliged to solve the dispute occurred in the village.

The function of the village chief as the mediator in disputes is strategic in supporting the justice in Indonesia, especially with the change of the ipso facto of Indonesia from gemeinschaft to gesselschaft. In strengthening the values, the function of village chief as the mediator based on local wisdom emphasized by Act number 6 of 2014 regarding Village must be used properly to widen the access from justice in society. [16]

The dispute resolution in Nagori Village of Tanah Java District in Simalungun is conducted with tiered steps which means that when dispute occurred it ought to be solved first in the village with the chief as mediator, if unsolved, it will be brought to the next level to Pangulu.

Mediator is to guide the mediation process and to facilitate the communication of parties. usually, a mediation is started with a preliminary conference between he parties and the mediator, and the mediator is to explain the process and the basic rule. This introduction is followed by information exchange in the conference or in written form. Most mediations are conducted in some form of meetings or private gathering with mediator whom gather information, listen to parties and ask questions. If agreement has been made, the mediator will assist in clarifying tand drafting the agreement. [17]

The dispute settlement by Pangulu Nagori or Chief of the village is conducted in 3 (three) steps of: (1) pra- meeting; (2) the meeting; and (3) decision making.

In the first step, pra meeting, the disputed parties are given the chance to talk about the objection or the issue and then about the report. The chief tend to advise to settle this with mediation with the chief of the village as the mediator. Most disputes in Nagori tend to be solved with mediation, not to the Police.

In the proceeding, Pangulu Nagori and the staffs, such as the secretary, the supervisors and others representing adat figures, and also the disputed parties attend the the deliberation to seek for the solution of the dispute.
When making the decision, the disputed parties are to listed to the agreement announced by the and the expense regarding the issue is burdened to the plaintiff.

Looking at the process, it actually similar to the model of proceeding in court by litigation, the difference here is the application of deliberation principle and also peace in kinship to reach one agreement between the parties which actually is a value inside mediation as a dispute resolution. Deliberation in proceeding is used since dialog has been made between Pangulu Nagori nd the attendees where any party can be an active attendee and free to state the opinion to each other. The dialog is directed wisely by the Pangulu as the leader of the proceeding until an agreement has been made by every proceeding attendee especially by the disputed parties.

Pangulu Nagori or the chief of the village as a respected figure has the authority in directing to reach an agreement where his skill will be the main factor in reaching a peaceful agreement.

Regarding the role of village chief or Pangulu Nagori he is the Authoritative Mediator or a mediator to assist the disputed parties in settling the differences of them, and has a strong position so that he has the potential in affecting the final result of the mediation.

The verdict made by the Pangulu Nagori is based on the agreement of the parties which is unwritten, but in certain condition, it is made in written form and obeyed by the parties regardless the inexistence of the force to obey the decision of the village chief. There is moral sanction for the party disobeying the verdict which is to be exiled in the village.

The disputed objects in Nagori village are varied but the most dominant is regarding land since it has economic value and also magic value.

The disputes settled with mediation or deliberation through the village chief or Pangulu Nagori are not limited to private cases but also criminal cases. This is because in adat law system there is no separation between private and criminal law, so there is no difference in settling or solving private case and suing a criminal case with Pangulu Nagori as the mediator. The examples of on-going case when this research was made are:

\section{A. Land ownership dispute between a group of society of Nagori Bahkisat with PT. Perkebunan Nusantara IV.}

This dispute began when a group of society ruled and used the unused land by PTPN IV in a long time and then the company intended to reuse the land, causing dispute occurred between them, the settlement of this dispute was done in deliberation of Pangulu Nagori where the party is given chance to deliberate in the Village courtroom with the assistance of Pangulu Nagori as the mediator in uniting the perception in facing the demand of the parties. but there was no agreement and finally the society decided to bring this suit to the District Court of Simalungun. 


\section{B. Land ownership dispute}

This dispute began with the land heritance where on the land, there was a certificate on one man as the owner but in reality there are 5 people owning the land as the heir of the parents. The land object was $2000 \mathrm{~m}^{2}$ Tanah Java District. This Dispute then settled with Pangulu Nagori Totap Mojawa gathering the five heirs in one meeting and explaining that the land wasn't a heritance object resulting the parties accepted the explanation.

\section{Underage Adultery}

Underage adultery of Laras (4 years old) happened when she was playing in the yard, and the perpetrator Candra Silaban (17 years old) as the neighbor used to offer snacks to the victim so the victim followed him to his house. The settlement of this case was begun with deliberation in the office of Pangulu Nagori Totap Mojawa with the attendance of the parties, LPM Nagori, the staff of the village, Gamot and witnesses, but this deliberation was failed since the victim didn't forgive the perpetrators so it was brought to the Police of Tanah Java Sector.

A dispute settlement conducted by the village chief are mostly to avoid any formal justification where the village chief is as the mediator directing the parties to be in one agreement.

The decision of the village chief which is the agreement of the parties has a binding power for the parties involved, and it is regulated in the explanation of Article 101 (e) Act number 22 of 1999 regarding Regional government jo Article 16 (3) Government regulation number 76 of 2001 of general reference of the village which mentioned that 'any dispute which has been resolved by the village chief is binding to the involved parties'. by that, the decision of Pangulu Nagori must be obeyed by the disputed parties.

In fact the disputes in Nagori village tend to be repeated. This is because the verdict is unwritten so there is no binding proof and there is no supervising institution to force the parties to implement and dropping sanction to anyone disobeying the verdict.

\section{CONCLUSION}

Mediation as a dispute settlement in Nagori Village Tanah Java District in Simalungun has be known by the society of Nagori village where the role of mediator is being run by the village chief or Pangulu Nagori. The dispute settlement in Nagori is using deliberation and kinship principle. The dispute settlement mechanism conducted in three steps, pra-meeting or pra proceeding, the proceeding and decision making. The proceeding here is informal which means that even though it is called as proceeding, it is done in deliberation, and the verdict is based on the agreement of the disputed parties which nevertheless must be obeyed. But unfortunately, there is still no supervising institution to implement or execute the verdict by the Pangulu Nagori.

\section{REFERENCES}

[1] Kansil, C.S.T., Pengantar ilmu hukum dan tata hukum Indonesia, Jakarta : Balai Pustaka, 2002.

[2] Runtung, "Keberhasilan dan kegagalan penyelesaian sengketa alternatif : studi mengenai masyarakat perkotaan Batak kota di Kabanjahe dan Brastagi", Dissertation, University of Sumatera Utara. pp. 13, 2002.

[3] Hakim. Guswan, "Kalo sara sebagai alternatif penyelesaian sengketa hukum adat suku Tolaki”, Clavia Law Journal, Vol. 9 No. 2, pp. 134. 2008.

[4] Weston. Maureen A., "Checks on participant conduct in compulsory ADR : Reconciling the tension in the need for good-faith participation, autonomy, and confidentiality", Indiana Law Journal, Vol. 76:591, pp. 592, 2001.

[5] Yahya, Chalik, "Perkembangan budaya hukum alternatif penyelesaian sengketa di beberapa negara di dunia : suatu studi komparatif', Warta Dharmawangsa Scentific Magazine, Dharmawangsa University, Vol. 7, pp. 103 - 117, January 2006.

[6] Hasjimzoem, Yusnani, "Dinamika hukum pemerintahan desa", Fiat Justicia Law Science Journal, Lampung : Faculty of Law Lampung University, Vol. 8 No. 3, pp. 473, July - September 2014.

[7] Usman, Rachmadi, Pilihan Penyelesaian Sengketa di Luar Pengadilan, Bandung : PT. Citra Aditya Bakti, 2003.

[8] Levi, Deborah L., "The role of apology in mediation", New York University Law Review, Vol. 72 : 1165, pp. 1170, November 1997.

[9] Margono, Sujud, ADR (Alternative Dispute Resolution) dan arbitrase proses pelembagaan dan aspek hukum, Bogor : Ghalia Indonesia, Bogor, 2004.

[10] Kosnoe, Moh., Catatan - catatan terhadap hukum adat dewasa ini”, Surabaya : Airlangga University Press, 1979.

[11] Hasan, Ahmadi, "Penyelesaian sengketa melalui upaya (non litigasi) menurut peraturan perundang - undangan”, Al-Banjari, Vol. 5, No. 9, pp. 95, January - June 2007.

[12] Noda, Yosiyuki, Introduction to Japanese Law, Tokyo : University Press, 1976

[13] Sunarno, "Praktek ADR (Penyelesaian sengketa di luar pengadilan) dalam menyelesaikan sengketa tanah", Legal Media Journal, Faculty of Law University of Muhammadiyah Yogyakarta, Vol. 13 No.1, pp. 20 34, 2006.

[14] Winarta, Frans Hendra, Hukum penyelesaian sengketa arbitrase nasional Indonesia dan internasional", Jakarta : Sinar Grafika, 2012.

[15] Sugiatminingsih, "Mediasi sebagai alternatif penyelesaian sengketa di luar pengadilan", Law Dynamic Journal, Malang, Vol. 12 No. 2, pp. 129 - 139, Juli - December 2009,.

[16] Sri Lestari Rahayu, Mulyanto, Anti Mayastuti, "Penguatan fungsi kepala desa sebagai mediator perselisihan masyarakat di desa", Yustisia, Vol. 5 No. 2, pp. 64, Mei - August 2016.

[17] "Mediation of investor - state conflicts", Note, Harvard Law Review, Vol. $127: 2543$ No. 8, pp. 2549, 2014. 